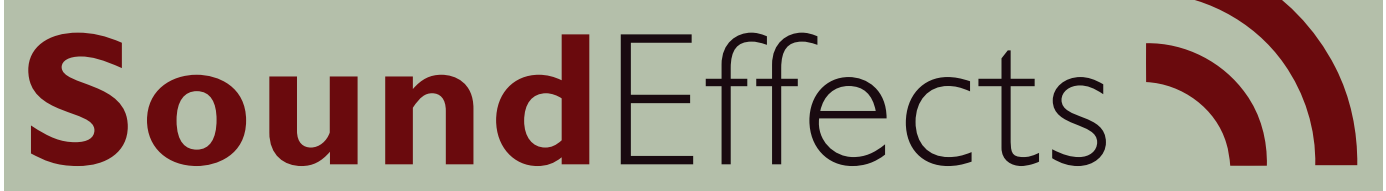

An Interdisciplinary Journal of Sound and Sound Experience

\title{
Jacqueline Waeber
}

\section{What's in a song:}

the case of Christopher Nolan's Inception

\author{
Jacqueline Waeber \\ Associate Professor of Music \\ Duke University \\ jw140@duke.edu
}




\begin{abstract}
Overblown cinematography and excess of visual attraction are the key features in Christopher Nolan's Inception (UK/USA, 2010), a film that eventually exhausts itself in its numerous tours de force. Yet, Inception's multi-levelled phantasmagoria cannot escape to the mere materiality of the objects that regularly invade its cinematic space, and that are invoked for what they simply are: things. Throughout the film, their fastidious presence points towards a desire that Kracauer has identified as an "urge for concretion." Not only does it provide a restraining counterpoint to the film's constant negotiation of dream-like spaces, but it also mirrors one of cinema's most enduring concerns: the obsession with the representation of the dense materiality of things.

In Inception, one of these things - indeed, the most important of all - is not an object defined by its tactile materiality, but the fragment of a song: Edith Piaf's 1960 recording of "Non, je ne regrette rien." In this essay, I argue that Inception privileges a haptic treatment of this aural fragment in order to present the song as thing. While this song may be replete with pre-existing connotations that could potentially impact on the audience's perception, its reduction to a brief fragment renders the meaning of its inter-textual potentialities illegible, but also singles out its sonic fabric in the aural foreground. Thus the paradoxical choice of a "vintage" recording that literally clashes with the glossy artificiality of the visual treatment (from objects to actors themselves). Although located at the purely aural level, the song fragment nevertheless resonates with Nolan's well-known claim to anchor his visual effects in "real life" by giving them a "realistic style of patina".
\end{abstract}

Since its release in the summer of 2010, Christopher Nolan's heist-sci-fi-gone-allFreudian blockbuster Inception has often been read as a film about the magic of cinema. While Nolan himself sought to dismiss the idea that it was all about 'filmmaking, ${ }^{1}$ the trope nevertheless persisted, along with another popular reading of Inception as a film questioning the values of late capitalism. Both readings even found themselves judiciously conflated in web blogger and author Mark Fisher's article on Inception published in Film Quarterly. Fisher's argument on 'the forces of predatory business' (2011, p. 45) that invade Inception's subconscious relies on a post from film blogger Devin Faraci (2010) in which the latter explains that Inception is a metaphor for cinematic production itself: Cobb (Leonardo DiCaprio) is the director, Cobb's partner Artur (Joseph Gordon-Levitt) [...] the producer, Ariadne (Ellen Page) the screenwriter, Saito (Ken Watanabe) "the big corporate suit who fancies himself a part of the game," Robert Fischer (Cillian Murphy) the audience' (Faraci in: Fisher, 2011, p. 40). ${ }^{2}$ It may seem blatantly obvious that Inception is all about exhibiting the mechanisms of cinematographic phantasmagoria. So obvious, perhaps, that only a 
handful of commentators have really tried to tackle this question at a less superficial level - Mark Fisher notably, to whom,

\begin{abstract}
Inception is less a meta-meditation on the power of cinema than, more interestingly, a reflection of the way in which cinematic techniques have become imbricated into a banal spectacle which - fusing business machismo, entertainment protocols, and breathless hype - enjoys an unprecedented dominion over our working lives and our dreaming minds. (Fisher, 2011, p. 42)
\end{abstract}

Without contesting Fisher's reading of Inception as a metaphor for the economic rationale underlying the banalisation of spectacular cinematic techniques, I want nonetheless to reframe this point by arguing that Inception posits a thesis according to which cinema, even when abandoning itself to any form of cinematic phantasmagoria, always ends by returning to what it was primarily conceived as the rendering of the physical density of the world, the materiality of the things and beings that inhabit it. Nolan himself may implicitly encourage this reading, considering his adamant reluctance to CGI techniques. ${ }^{3}$ While Mark Fisher and other commentators have narrowed their argument on Inception as to present the issue of reality versus (Freudian) imaginary at the core of the filmic narrative, ${ }^{4}$ I intend to move away from this binarism and propose another reading of this film's 'undreamlike-ness', a claim that has frequently been construed as criticism by commentators since the film's release (Fisher, 2011, p. 40).

In this essay, I will argue as well that the objects in Inception are not self-contained within their only essence as objects, but recover their thingness. The disproportionate effort that animates Inception in trying to convince us of its own cinematic phantasmagoria is inversely proportional to the film's capacity for detaching itself from the materiality of things and beings. The more the film tends towards phantasmagoria, the less it can detach itself from material things; thus Inception remains enmeshed within an unstoppable process of reification. As I will show, it is no coincidence that much of the visual appeal of Inception epitomises the dense presence of things, the overwhelming presence of their materiality, as reflected in the film's closing shot of the top spinning on the table - metal and wood. The question raised by this frustrating ending may not be so much if the top will stop or spin forever; rather, this final shot reminds us that, when processed through the cinematic medium, phantasmagoria cannot resist attraction to materiality. In that respect, Inception aligns itself rather traditionally within theories on cinematic materiality and its engagement with reality that has arisen during the first half of the twentieth century. Inception's inescapable attraction to things could be justified a posteriori by Lesley Stern's discussion on cinematic materiality, when invoking Siegfried Kracauer's claim on cinema as led by the 'blind drive of things' and its 'urge for concretion' (both quotes from his Theory of Film), as well as Jean-Louis Comolli's refer- 
ence to 'the [cinematic] force of things' (Stern, 2004, p. 400). It is worth providing the whole context of Comolli's quote, as it echoes even more uncannily with Inception:

\begin{abstract}
I believe that in the first Lumière films, it was already the force of things that captured cinematic representation; this force was equal to that of the form of representation that claimed to capture those things; it was the force of things as they assert themselves. For people were wonderstruck by the trembling of leaves on the trees-a good example, since the wind bloweth where it listeth-which produced an effect, an effect of the real. (Comolli \& Michelson, 1999, p. 42)
\end{abstract}

Nolan himself seems to have made a nod to the most emblematic Lumière film, 'The arrival of a train at La Ciotat', during the first dream level of corporate heir Robert Fischer in rainy LA, with the irruption, as much dreamlike as undreamlike, of a freight train in the middle of a car chase taking place in the jammed traffic: a sequence that was not realised through CGI but shot using the replica of a freight train made of fibre glass mounted on train wheels. ${ }^{5}$ Inception offers a distantiated reloading from the archetypal confrontation that D.N. Rodowick identified in films such as eXistenZ, The Matrix, Dark City, Thirteenth Floor, films in which ' $t$ t] versus the analog was the heart of narrative conflict [...] as if cinema were fighting for its very aesthetic essence' (Rodowick, 2007, p. 4). Distantiated, if not ironic, for if Inception offers the binary reading of dream/reality, thus implying two different levels of narration, it ends by obfuscating such confrontation and making it obsolete; the stuff of which dreams are made appears to be the very same as the stuff of which reality is made. This would confirm that Inception is indeed a film 'about the magic of cinema' but not for celebrating cinema as the privileged locus for phantasmagoria. On the contrary, indexicality is for Nolan a sine qua non condition justifying his nearly systematic rejection of CGI effects:

\title{
However sophisticated your computer-generated imagery is, if it's been created from no physical elements and you haven't shot anything, it's going to feel like animation. [...] The problem for me is if you don't first shoot something with the camera on which to base the shot, the visual effect is going to stick out if the film you're making has a realistic style or patina. I prefer films that feel more like real life, so any CGI has to be very carefully handled to fit into that. (Nolan: in Ressner, 2012; emphasis added)
}

In so doing, Nolan, arguably the fiercest defender of celluloid in Hollywood film industry, appears as a decidedly nostalgic film director that has so far shied away from the recent technological transition from celluloid to digital. ${ }^{6}$ The irruption of the freight train not only perfectly emblazons Inception's graphic rendering and fabrication of materiality, but also depicts the ongoing tension of analog versus digital in current mainstream cinema industry.7 However, this 'urge to concretion' that characterizes Inception is in the end fulfilled by the concourse of a parameter located outside the visual: the active engagement of the aural level. As I will show, Inception's stance towards materiality is enacted through the entanglement of the 
aural with the material, creating a convergence of the sense of hearing and the sense of touch that exemplifies Laura U. Marks' definition of 'haptic sound': 'One might call "haptic hearing" that usually brief moment when all sounds present themselves, to us undifferentiated, before we make the choice of which sounds are most important to attend to' (Marks, 2000, p. 183). The insistence on thingness in Inception is matched by a similar phenomenon occurring at the aural level through a process of excessive enhancement - a form of aural close-up, magnifying the very texture of sound. But not any sound: the sound of a song.

\section{The hermeneutic fallacy}

But first, what song? Just googling these two words, 'inception' and 'song', will remind anyone that following the release of Inception, there was much discussion about one song in particular, 'Non, je ne regrette rien', in its 1960 recording by the French singer Edith Piaf. This recording, or at least a brief fragment of it, was heard at specific moments during Nolan's film; it was played by a team member remaining 'outside' the dream (say dream $x$ ) in order to signal to his companions (those inside dream $x$ ) that time had come to leave their dream, whether to go back to reality, or to re-enter into another dream $y$ (in the case of dream $x$ being itself contained within dream $y$ ).

Discussions on this song in Inception were themselves related to a video originally uploaded on YouTube that quickly went viral only a few days after the release of the film. Entitled 'Inception Music Comparison', 'the video aimed to show the origin of the low, rumbling chords heard in the cue 'Dream Is Collapsing' from Hans Zimmer's score for Inception. This cue was heard each time the members of Cobb's team were about to wake up from their dream. The video played two very brief passages in successive order, and then, superimposed: first, the cue and then the very beginning of 'Non, je ne regrette rien', but at a slowed down speed. As it resulted from the comparison, and most specifically from the superimposition of both fragments, the two passages turned out to be the same: Zimmer had used the opening measures of the instrumental introduction from the Piaf song, in which is heard the scansion of a low $g$ on a single iambic rhythm (short-long, here the eight note-quarter note succession; see example 1). ${ }^{9}$

This revelation caused much wonderment and became the subject of many online discussions on specialised websites, social networks, blogs and news media. ${ }^{10}$ Asked a few days after the release of the viral video, Hans Zimmer expressed his surprise at 'how long it took them to figure it out' (Itzkoff, 2010). He could have added that the video had only identified one out of the two borrowings he took from the song, for Zimmer did not only use the iambic rhythm; several other cues from the Incep- 

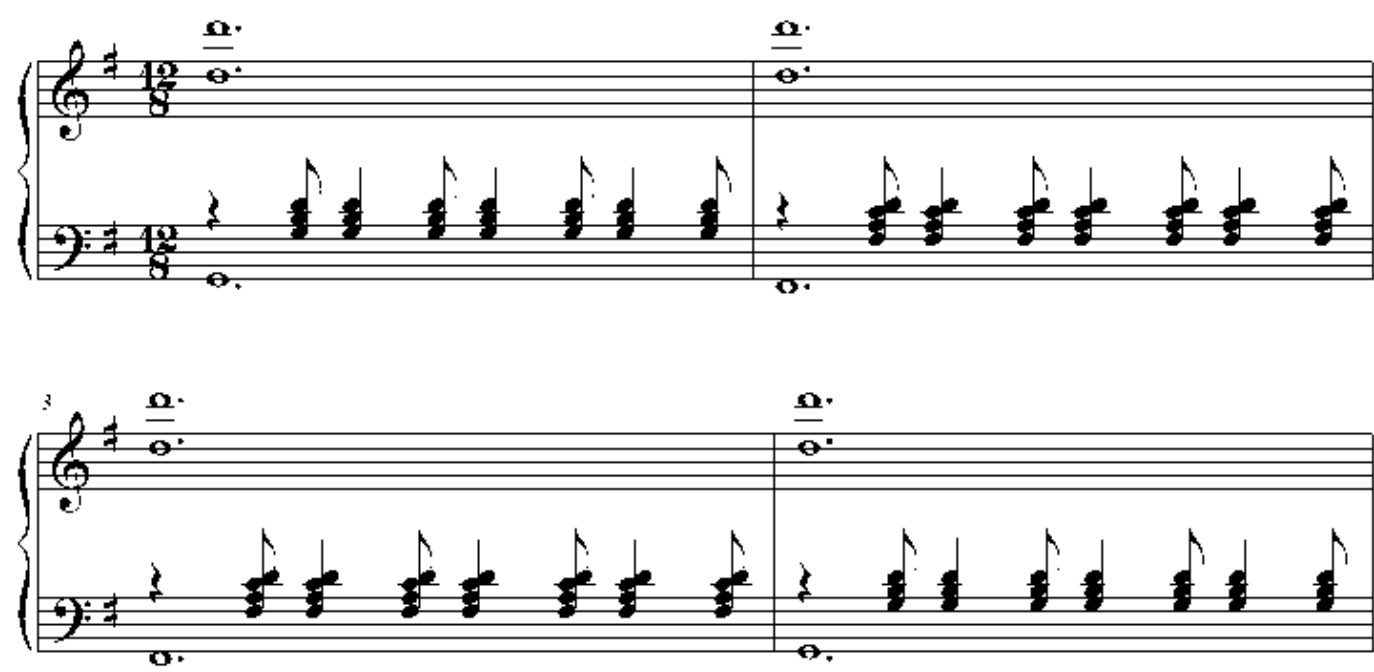

Example 1. Opening bars of 'Non, je ne regrette rien', music by Charles Dumont.

tion soundtrack are based on a very simple melodic material, the semi-tone $g$ - $f \#$ that characterises the bass line of the song (see example 1, left hand, bass line $g$-f\#-f\#-g). ${ }^{11}$

In terms of compositional technique, though, the borrowings would not provoke such wonderment. That kind of motivic work on small melodic/rhythmic/harmonic material - here a rhythmic augmentation of the iambic rhythm through the slowing down of the tempo - is very much part of the tradition in Western music, going back to the technique of 'augmentatio' widely used during the Renaissance and medieval periods. Why then did this compositional technique of borrowing generate so much astonishment and become such a hot topic in the blogosphere? Certainly, it offered an easy invitation for drawing a parallel with the fact (at least within the fantasy world of Inception) that during dreams time might be perceived as slower than in reality. But more importantly, the fascination exerted on audiences by this rather conventional musical sleight of hand technique must have touched on a more significant issue about our (mis)conceptions of musical composition, still largely held in our culture as an intellectual exercise on the verge of high mystique (and, certainly, the blogosphere remains the most privileged platform for verifying the persistence of such commonplaces). The bottom line here is that such a small musical motive has nevertheless the potential to generate a whole symphonic score. Thus, the claim frequently found all over the web and in print media was that the viral video had unveiled the 'secret' of the Inception soundtrack. Zimmer's entire score had literally come out of the song 'Non, je ne regrette rien' - as illustrated by this title from The Guardian: 'Inception soundtrack created entirely from Edith Piaf song' (Michaels, 2010). Although much exaggerated, such a claim is symptomatic of a widely held fascination in Western culture for musical scores purportedly generated from one 
single musical cell. What can be identified here is a fantasy that goes back to early Romantic discourses on music, the underpinning of which found its paramount expression with Goethean organicism ${ }^{12}-$ a fantasy that Zimmer himself is happy to indulge in, as revealed by his own biological metaphor:

I had to go and extract these two notes out of a recording [...]. I love technology, so it was a lot of fun for me to go and get the original master out of the French national archives. And then find some crazy scientist in France who would actually go and take that one cell out of the DNA. (Itzkoff, 2010)

Slightly correcting the explanation given by the viral video, Hans Zimmer stressed that the passage from his own score was not just a slowed down version of the opening rhythm on the $g$ major chord of the song. It was a literal act of reappropriation of a said passage, for the recording of the song's excerpt itself had been assimilated within the texture of his symphonic score. The score was supposedly conceived from 'one cell' - 'these two notes', as Zimmer put it - itself taken 'out of the DNA', that is to say the recording of Piaf's song as original matrix. Such hermeneutic readings - as tempting as they might be - are plausible but not necessarily true, and in any case, it does not redeem the average quality of Zimmer's unsurprising underscoring, typical of the 'non-diegetic soundtrack' grafted onto the filmic narrative, written in the standard symphonic style favoured in mainstream Hollywood industry. The main aim of Zimmer's soundtrack is commentative; once we have exhausted all variations on 'the music reinforces', 'the music describes', 'the music stresses', 'the music emphasises', 'the music reflects' and so on, there is not too much left. The organicist fantasy, on the other hand, seems to promise and deliver far more. First, because Zimmer's soundtrack only exists by virtue of a specific musical material that is itself consubstantial to the diegesis of Inception. The 'Piaf song' is the very material that regulates the existence of the fiction and the dreams generated within it, thus considerably loosening up the rigid binary of 'diegetic' and 'non-diegetic' music. The song is what prevents the chaotic interference of dreams, but also their sudden interruption - especially as the latter would cause, when the dream is induced by extreme sedation, the symbolic death of the dreamer or the subject of the dream, precipitating him or her into eternal limbo, described as 'unconstructed dream space'. This fragment of the Piaf song ${ }^{13}$ acts as a 'signpost' (to use Zimmer's term) (Itzkoff, 2010): it alerts the dreamer that time has come to abandon the current dream (which may however be itself contained within another dream), preventing the lethal engulfing in the Lacanian Real. The song's function is to bring back the reality principle in order to regulate the register of the Symbolic - the latter momentarily run amok during the dream.

The difficulty to accommodate an understanding of the music's function in Inception through the limitative binarism of 'diegetic/non-diegetic' can be observed 
at another level. ${ }^{14}$ The Inception soundtrack uses the studio recording made by Piaf in 1960 of the song 'Non, je ne regrette rien', written in 1956 by Charles Dumont with lyrics by Michel Vaucaire. Still being held today as one of the most emblematic songs in the canon of the 'Chanson française', the song quickly became iconic of Piaf herself by echoing her own tormented life marked by excesses, passions and dramas of all sorts, from her addictions to the loss of her lover, the boxing champion Marcel Cerdan who had died in a plane crash in 1949. The song's lyrics easily encourage such a reading:

Non, rien de rien

Non, je ne regrette rien

Ni le bien qu'on m'a fait

Ni le mal, tout ça m’est bien égal.

Non, rien de rien

Non, je ne regrette rien

C'est payé, balayé, oublié

Je me fous du passé.

Avec mes souvenirs, j'ai alluméle feu

Mes chagrins, mes plaisirs, je n'ai plus besoin d'eux

Balayées les amours, avec leurs trémolos

Balayées pour toujours, je repars à zéro.

Non, rien de rien

Non, je ne regrette rien

Ni le bien qu'on m'a fait

Ni le mal, tout ça m’est bien égal.

Non, rien de rien

Non, je ne regrette rien

Car ma vie, car mes joies

Aujourd'hui, ça commence avec toi.
No, nothing at all

No, I don't regret anything at all

Neither the good that was done to me,

Nor the evil. They're all the same to me.

No, nothing at all,

No, I don't regret anything at all

It's all paid for, wiped out, forgotten,

And I don't give a damn of the past.

With my memories I've lit a fire.

My sorrows, my pleasures, I don't need them anymore. Wiped out, my romances, with their tremolos.

Wiped out forever, I start all over again.

No, nothing at all,

No, I don't regret anything at all.

Neither the good that was done to me,

Nor the evil. They're all the same to me.

No, nothing at all,

No, I don't regret anything at all

Because my life, because my joys -

Today, that begins with you.

This song is about overcoming one's own past. Could there be a more perfect underscoring to what Cobb is struggling with, since he is unable not to care about his own past? Because he wishes so much that he could not care, the song seems to resonate as an aural embodiment of the oblivion Cobb desperately tries to reach, and the replete number of comments that have flourished on the Internet (and then elsewhere) since the release of the film attest to the popularity of this hermeneutic approach.$^{15}$ Yet these are considerations that prioritise the implications contained 'within' the song and their relation to the film plot. Certainly, to anyone knowing what the song is about, and more precisely, knowing the meaning of its lyrics, those 
connections may seem obvious. At stake here is the level of knowledge shared by film viewers. Indeed, who among the audience is really aware of this song and thus aware of the historical and cultural subtexts that this song conveys? ${ }^{16}$

Because they are strongly associated with, if not defined by the semantics of their lyrics, songs can offer misleading cases in which textual elements easily divert our attention away from the purely sonic fabric of the song. Since the listening of the Piaf song by Cobb and his team corresponds to a moment of recognition, it is indeed a song about recollection. As such, this song re-enacts a most enduring trope in our Western culture: not so much the connection between song and memory, but rather the notion of song as memory. However, it would be a mistake to assign this to its lyrics, for they have nothing to do with it - what matters here is the somatic (the song as sound, the act of listening to the song, and how the song is listened to) over the semantic (its lyrics). And even if the lyrics indeed connect with the trope of recollection, then it is rather a coincidence. Paraphrasing Gertrude Stein, we could say that, 'a song is a song is a song', and as such, its identity as song is already a conveyor of nostalgia, triggering our memories. Songs' vivid power of recollection can be perfectly summarised by one of the Peanuts' comic strips, in which Charlie Brown addresses Lucy in such terms: 'This song always depresses me. It brings back such sad memories ... you know what I mean? I've never heard another song that depresses me the way this one does ... play it again, will you?' That the 'play it again' echoes the famous misquotation of Michael Curtiz's Casablanca ${ }^{17}$ is itself an exemplary cinematographic case of a song specifically used as a memory trigger, because of the act of recognition it implies. The Piaf song in Inception aligns itself along this trope of listening experienced as trauma: to tear the dreamers away from their dream. But it is also a perversion of the trope, for while songs tend to send us back to the past, by inducing nostalgia and recollection as a form of 'awake dream', it does the exact opposite here; the refuge is not the dream, the idealised past, but the reassuring presence of reality - which could support another popular reading of the plot in Inception as being entirely Cobb's dream. ${ }^{18}$

During the whole duration of Inception, the Piaf song is never heard in its entirety. Only a fragment is heard, and when heard it is hardly recognisable through the distortion of the slower tempo, the emphasis on the iambic rhythm and the semitone $g$-f\#. One element that remains clearly recognisable, helping us identify this music as not just 'any music' but a song, is the presence of a voice. Characterised by their ambivalent quality, voices can be purely timbral elements, but also conveyors of meaning through the sung text - what Julia Kristeva had already stressed with the notions of 'géno-chant' and 'phéno-chant' reused by Barthes in his 1972 essay 'Le Grain de la voix.'19 To give emphasis to the meaning channelled through the song's lyrics, and other musical conventions and tropes, is an exercise in decipherment that takes place at the level of the phéno-song - Barthes's 'tissue of cultural values' 
(Barthes, 1977, p. 182). The validity and raison d'être of such decipherment presuppose a communicative exchange that requires a common understanding of these 'cultural values' shared with the audience. It is at the level of the phéno-song that a hermeneutic reading such as the one outlined above can take place: the Piaf song, or rather what this song means through its lyrics, is the marker of Cobb's own incapacity to overcome his past. However, Inception does the contrary. Here, the aural presence of the Piaf song detracts from the conventional expectations of the traditional treatment of songs in Hollywood mainstream films, primarily because its aural presence is enhanced by gestures of negation. Exclusively heard through its truncated form, the Piaf song is played five times during the whole film (only the sixth and very final occurrence during the end credits, is slightly longer ${ }^{20}$ ). As for the narrative, it does not offer any connection that would contextualise the meaning of the song - and no contextualisation is made as well during the end credits. Most likely, Nolan never intended to insist on its semantic meaning, particularly considering that the characters never make any explicit reference to this song, save for referring to its function as a 'signpost'; the song is throughout the film simply referred to as 'the music' or 'a musical countdown'. ${ }^{21}$

Reducing Piaf's song to a short fragment strips it of anything that would enhance its function as a purveyor of meaning; the fragment's anchoring in a specific signified is weakened. In the end it becomes a pure aural presence that eludes signification. This aural fragment is located in a grey area that Roland Barthes had referred to as the 'peripheral zone' of the filmic sign. This zone is constituted by what Barthes refers to as the 'signes décrochés', a hardly translatable expression, but one that should by all means not be mistranslated as 'broken signs' ('signes brisés'), since 'broken' implies a definitely damaged, shattered cohesion between the signifier and the signified: "[T] he peripheral zone is constituted by what could be referred to as floating signs [signes décrochés], where the analogy between the signifier and the signified is, so to speak, disjointed, unexpected." (Barthes, 1960, p. 1040; my translation). ${ }^{22}$ In such a peripheral zone the signifiers, whether visual or aural, float without being attached to a specific signified. The 'signes décrochés' do not necessarily imply a definitive separation between signified and signifier, but rather a loosening up of the relation between the two. Their matching remains potentially possible, as well as their unmatching - they can be 'disjointed'. The fragment of the Piaf song is a case of such 'signe décroché'; it has been expurgated of its signified, rendering illegible its meaning(s) in order to prevent any intertextual potentialities that could arise, if not to nullify these as much as possible. Inserted in the film as an 'objet trouvé, the recording of the Piaf song does not fit in with the rest of the diegetic environment of Inception. This brings us back to our question concerning Nolan's choice of this song in this specific recording - a song that seems not to have any 
close specific and personal ties with the characters, that comes from a different period and culture and is sung in a foreign language.

The implications of the song as an 'objet trouvé', and as 'signe décroché', can be assessed by examining more closely one sequence, in which we, the audience, are confronted for the first time with the song's recording, without yet being aware of its function of 'musical countdown'. In the Shinkansen train, a Japanese boy working for Cobb's team places the headphones on Nash's head (the first dream architect, soon to be replaced by Ariadne) and plays the Piaf recording of the song that will wake him up from his dream, right now happening in Saito's apartment, itself located in an unnamed Arabic city during an uprising. Waking up Nash will also wake up Artur and Cobb, who are asleep in the same compartment, and who are connected as dream subjects to Nash's dream. As the close-up focuses on Nash's face, the MP3 player starts playing the song. But what is heard is not the song's instrumental introduction; we (the audience) are immediately confronted by Piaf's voice singing the first verse 'Non, rien de rien ...' This truncated beginning has a simple purpose, which is to inform us that we are listening to a song; hitting us from the start, Piaf's voice is the best way to make us aware of this. What immediately follows is a medium shot on Nash, but this time awake in his dream and standing up in Saito's apartment. The other dream subjects, Cobb and Artur, can also hear the song - they react accordingly, notably Artur, who looks anxiously out the window to check on the progress of the uprising. The song continues, uninterrupted, although aurally distorted by the amplification through crescendo (itself the result of the very melodic outline of the song and its instrumentation dominated by brass). The relocation of the song within the dream may tend to obscure its sonic allure - to the point of rendering the song nearly unidentifiable - but it also enhances its most defining features (the iambic rhythm, the semitone interval $g$ - $f \#$ ). While Artur looks through the window, its fragment resonates within the dream, as if coming from a distance, with the distorted echo effect on Piaf's voice that will be used in all four subsequent occurrences of the fragment.

During this whole sequence, an intriguing event happens in Saito's apartment. After a brief fight with Cobb, Saito is thrown on the floor, covered by a thick carpet made of long beige threads. Touching the carpet with his hand, Saito realises that he is still in a dream. This is because Nash, the dream architect, had neglected an important detail during the preparation of the dream. Saito's tactile feel of the carpet makes him aware that the carpet is, as he says, 'made of polyester' - whereas, had this taken place in the awake reality, it should have been made of wool. This moment also marks a significant pause in the dramatic pace of this action-packed sequence, with the imminent threat of the uprising. The script decidedly takes pleasure in dwelling on that moment, with the camera lingering on a close-up of Saito's face against this densely textured carpet, his fingers touching the threads of 
synthetic wool. However, something else happens simultaneously, but on a different sensory level; a similar feel of density emanates from the remnant of the song, creating an aural saturation with the distortion resulting from the slowing down of the song's fragment. While the visual close-up on Saito accentuates the frayed texture of the carpet and enhances a dramatic rendition of colours with the contrast between Saito's copper tone skin and the pale texture of the carpet, the aural closeup magnifies a texture detail of the recording (the slow hammering of the low gs).

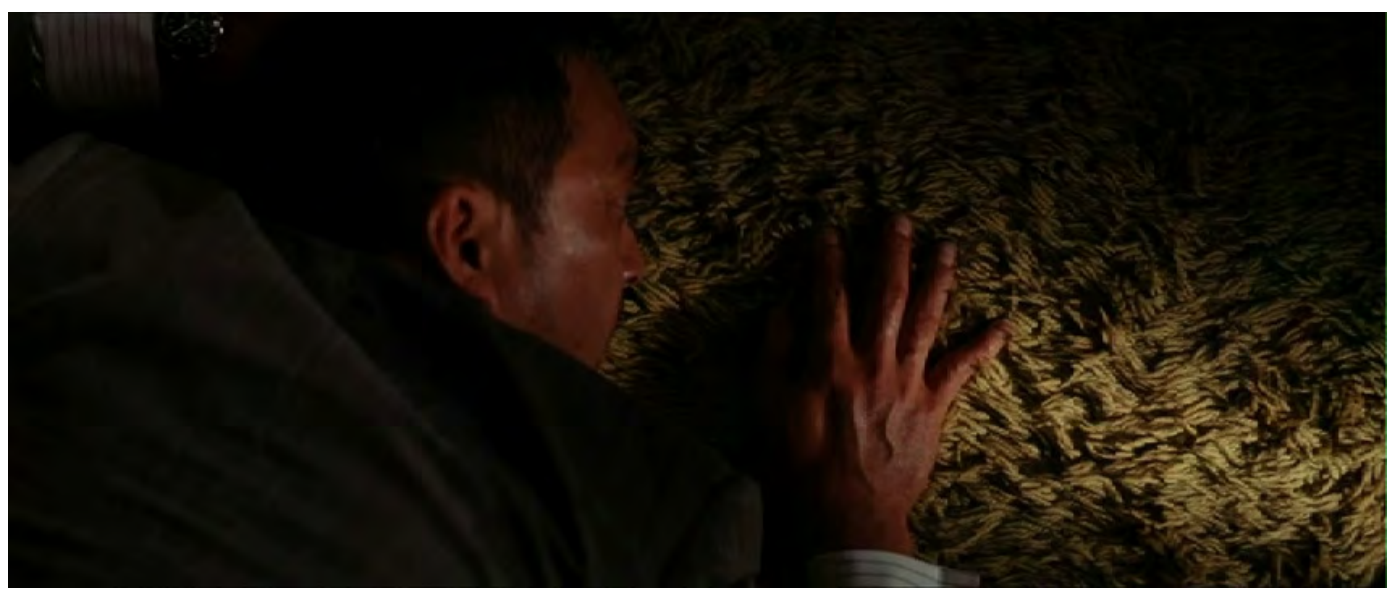

[Saito] 'I always hated this carpet. It's stained and frayed in such distinctive ways ... but very definitely made of wool. Right now, I'm lying on polyester. Which means, I'm not lying on my carpet in my apartment ...'

By focusing on a very small detail, the aural close-up turns into an anamorphosis. ${ }^{23}$ Literally, what happens during this shot is the juxtaposition of two fragments, framed distinctively. This not only puts us in a situation of heightened receptivity, but also in a position that mirrors what Saito is experiencing: he, through his sense of touch, and us, through our senses of sight and hearing. As Vivian Sobchack puts it,

[e]ven at the movies our vision and hearing are informed and given meaning by our other modes of sensory access to the world: our capacity not only to see and to hear but also to touch, to smell, to taste and always to proprioceptively feel our weight, dimension, gravity, and movement in the world. In sum the film experience is meaningful not to the side of our bodies but because of our bodies. Which is to say that movies provoke in us the 'carnal thoughts' that ground and inform more conscious analysis. (Sobchack, 2006, p. 60; emphasis in original)

As spectators, our sense of touch cannot be stimulated, but it is nevertheless encouraged through our sense of vision; thrown to our eyes and ears as bait, the audiovisual clash engages us in a 'participatory notion of spectatorship' that Laura U. Marks has identified in Bergson's 'attentive recognition' (Marks, 2000, p. 48). The audiovisual image, with the momentary change of pace in the action and its accumula- 
tion of aural and visual details, becomes the interface through which our attention as spectators reaches a state of heightened perception. The aural close-up on the song's textural details forces us to be aware of its aural presence through a sense of 'aural' touch - our haptic vision parallels Saito's tactile attention.

\section{The unbearable heaviness of things}

The sense of touch is crucial in Inception, for it is a symptom of what weighs so much upon this film, coming back to the issue mentioned earlier about Inception being a film driven by a desire for a filmic phantasmagoria inevitably aborted by the dense presence of objects. Cobb and his team rely on the use of a totem, a small object they keep with them constantly. Cobb's totem is a top, Ariadne's totem is a weighted chess piece (a bishop), Artur's totem is a loaded die, Eames's totem consists in two poker chips. Defined by their material thickness (weight, density, consistency), all these totems engage the sense of touch, helping their possessors to confirm that they are back in reality. If so, the totems will behave in a logical way: the top will spin, but then inevitably stop; the chess piece will fall on a specific side; the loaded die will always give the same number; the chips will not multiply themselves when rubbed. These totems exemplify at their best the constant enhancement of the materiality of objects. Visually speaking, Inception is a lush and densely textured film, yet it still relies heavily on spectacular effects that dematerialise the physical density of the cinematic things and beings through an undermining of the Newtonian laws of physics: the frozen-like explosion in Paris (realised with high-speed cameras) or the city folding upside down, the zero gravity fight in the hotel hallway, the asleep dreamers floating from their hotel room to the elevator ...

Inception is inscribed in a well-identified trend in contemporary cinema - from documentary to intercultural cinema: a growing tension between immateriality and corporeality (whether of human bodies, of their skins or the concrete, dense mass of inanimate things). Except that in Inception such immateriality is made visually possible through the most extreme material means - Nolan's quasi-systematic refusal of CGI techniques. Immateriality can embody various forms - notably with digital encoding and, of course, CGI - yet it is expressed in Inception through a specific fictionalisation of the cinematic phantasmagoria (the elaboration of dreams) that requires a significant amount of preparation, training, a perfectly well-organised teamwork, not to mention a sophisticated technical support. All taking place during the dreams, the most spectacular sequences of the film presuppose a material inertia of the objects, itself the defining feature of the totems. Even the machine used by Cobb's team to provoke the state of dream is not immune to the heaviness of its material condition. Set into an aluminium briefcase, the machine's core is a mechanism in black and grey steel, with a circular button made of soft white sili- 
cone, glowing red when the machine is activated. The dreamers connect themselves to the machine with a transparent plastic cord tied around their wrists. The soft flexibility of the cords and the silicone button sharply contrasts with the rest of the device. ${ }^{24}$ Settings are also affected: the coldness and opulence of a capitalist environment - those shiny business lounges and corporate five-star hotels - stand in perfect contradistinction to the equally 'more-than-real' rendition of the crowded and sweaty atmosphere of the unidentified Arabic city or the narrow streets in Mombasa. This even seems to have affected the characters' external appearance, from casual to chic tailoring for Cobb and his (almost all-male) team, not to mention the plasticity of the actors' faces as smooth as waxwork figures. This painstaking effect of hyperrealist rendition in Inception possesses paradoxically an overall perfection that is literally all over the film; thus, problematically, obliterating the difference between reality and dream.

As I have argued above, the way Inception manages to renegotiate the tension between phantasmagoria and materiality reminds us of the attraction that things exerted on the cinematic medium since the origins of cinema. The point has been recently discussed by Lesley Stern in relation to cinematic things, the value of which cannot simply be reduced to a mere function that is 'inflected within an emblematic or hermeneutic register, [and that] is primarily narrative' (Stern, 2004, p. 394). Stern is herself indebted to Bill Brown's thing theory:

\footnotetext{
You could imagine things [...] as what is excessive in objects, as what exceeds their mere materialization as objects or their mere utilization as objects-their force as a sensuous presence or as a metaphysical presence, the magic by which objects become values, fetishes, idols, and totems. Temporalized as the before and after of the object, thingness amounts to a latency (the not yet formed or the not yet formable) and to an excess (what remains physically or metaphysically irreducible to objects). (Brown, 2001, p. 5)
}

It is through the sense of touch that the objects in Inception are turned into totems. The choice of this noun neatly casts a spell by heightening the objects' purely material essence, while at the same time preserving them from any urge for hermeneutics. Not only are they objects, but they have also returned to their primordial state as things. The recording of Piaf's song is also such a thing: an aural totem, the function of which is similar to its material counterparts..$^{25}$ While the thing-as-totem is utilised as a way to verify the return to reality, the recording is a signpost informing us of the proximity of reality. The similarity does not end here, as the thingness of the totems requires from their possessor an act of recognition. Just as the totems are defined by their material density, the recording of Piaf's song also possesses such an unmistakable 'aural thingness'. This is why the song-as-thing, obfuscating any attachment to a specific signified, is revealed to us by this aural close-up that enhances a detail from the texture of the song's recording, echoing the visual close- 
up of the heavily textured carpet. As mentioned earlier, the song as a whole and as a potential conveyor of meaning (through its lyrics) has no importance at all in Inception; the point here is not about knowing what the song is about or being able to recognise this voice as Piaf's. What matters is to acknowledge the thickness and resonance of her unique voice, both textural qualities referring to Barthes's 'grain of the voice', for this is the 'thing-ness' of the song. By focusing on a brief fragment in which Piaf's voice is heard (especially the word 'non' is here considerably extended through the slowing down of the tempo), the recording is not enslaved to any specific signified; its aural presence acquires a devastating potential as pure signifier. Unburdened by its layers of extra-musical connotations, the song, or rather what is left of it, returns back to its state as a pure aural thing.

That said, the very aural material of Piaf's recording possesses another unmistakable quality: its historicity. Paradoxically, this could restore the song's potentiality to act as a signified - but once more, would this not depend on the spectators' knowledge of the song, since those who do not know it, or its singer, would then not be aware of this song as indeed an object with history? This supplementary value attached to the song's fragment has no incidence with what the song means or could potentially mean. More importantly, this would not affect uninformed audiences, for it is all about the way it sounds. I refer here to the specific qualities of Piaf's original 1960 recording: its instrumentation, typical of a 1950s-1960s variety orchestra (conducted by Robert Chauvigny); the monophonic rendering of the sound, despite its remasterisation; and, of course, Piaf's idiosyncratic and tremulant vibrato - no one sings like this anymore. The recording, the orchestra and the voice are characterised by a sound from another time: in one word, dated. Despite the busy aural environment of Zimmer's soundtrack, we cannot escape the sense of past that emanates from this recording.

A few days after the film release, The Wall Street Journal published an inaccurate information that nonetheless perfectly illustrates this point: 'who sings the lovely song that plays in the background during the dream sequences? It's sung in French by a chanteuse whose vocals have the scratchy quality of old Victrola recordings [sic]. The answer: Edith Piaf's “Non, Je Ne Regrette Rien"' (2010). The comparison with the 'old Victrola recordings', popular during the 1900s, is, of course, inexact, as is the mentions of scratches - for there are none of these in the portion of the 1960 recording, all removed by the remastering. Of course, this may just be trivia, and such information abounds on the Internet and in print media; but patently wrong though it is, the description of The Wall Street Journal is accurate in terms of the intention behind the choice of this very recording. If the Piaf recording stands out in Inception and is noticed by spectators, it is not because of the implicit hermeneutic reading it can give way to; its quality as a "historical" recording is certainly not about emphasizing its cultural or semantic bagage. On the contrary, the 
song must resonate as an intentional mismatch within the diegesis. In so doing, it acquires an out-of-place quality, illustrating Stanley Cavell's claim that things in film are 'always already displaced, trouvé (i.e. that we viewers are always already displaced before them)'. (2005, p. 9)

The uncanny resonance of the song fragment as 'objet trouvé' conveys these aural markers of past-ness; it indexes the song-as-thing (and nothing more) through the emphasis of an aural hapticity, triggered by the monophonic aura of the original recording - evocative enough to create the aural illusion of the scratches of the needle in the grooves. Thus, the intrusion of Piaf's recording adds a value of 'faux vintage, ${ }^{26}$ a coating of realism that induces a sense of 'genuine historicity' - indeed a sense of past-ness.

While this may seem at odds with the sleek visual perfection that characterises the diegetic world of Inception, the song's vintage quality is what brings to this contemporary dystopia the scratches of time: not history itself, but a sense of it. As Laura U. Marks puts it, 'Both film and video become more haptic as they die. Every time we watch a film, we witness its gradual decay; another scratch, more fading as it is exposed to the light, and chemical deterioration [...]' (2000, p. 172). The song fragment compensates for what is missing in Inception, with its filmic narrative in which time's inexorable linearity has been rejected in favour of a concentric conception, since the temporal space of a dream can potentially open up into a newer, wider temporal space.

Inception is then not so much about a grandiloquent celebration of cinematic phantasmagoria. What is left in the end is the haptic, ever present materiality of things-and yet the most powerful of these is rendered through the most immaterial medium of aurality: it is by such detour that Inception brings us back to the very origins of cinema, and its obsession with things.

\section{ANNEX 1.}

Survey on Inception, 68 participants.

1. When watching the movie for the first time:

1. a) I noticed there was a song: 45

1. b) I did not notice there was a song: 23

3. Why do you think Christopher Nolan chose this song? (more than one answer possible)

3. a) because of the singer's voice: 16

3. b) because of the actress Marion Cotillard, who played Edith Piaf in La Vie en rose: 18

3. c) Because of the meaning of the song: 31

3. d) Other: 24 


\section{FILTERED RESULT (45 participants)}

1. a) When watching the movie for the first time, I noticed there was a song,

2. a) but I had no idea which song it was. I had never heard it, and I didn't know who was singing it: 7

2. b) but I only had a vague idea of it, or had probably already heard it in another movie, or elsewhere: 8

2. c) the tune of which sounded familiar to me, or I was able to name the song (but not the singer): 5

2. d) I recognized the song and the singer: 25

FILTERED RESULT (8 participants)

1. a). When watching the movie for the first time, I noticed there was a song,

2. b) but I only had a vague idea of it, or had probably already heard it in another movie, or elsewhere.

3. Why do you think Christopher Nolan chose this song? (more than one answer possible)

3. a) because of the singer's voice: 0

3. b) because of the actress Marion Cotillard, who played Edith Piaf in La Vie en rose: 1

3. c) Because of the meaning of the song: 6

3. d) Other: 1 .

\section{References}

Barthes, R. (1960). Le problème de la signification au cinéma. In: Barthes, CEuvres complètes, vol. I (p. 1040). Paris: Seuil.

Barthes, R. (1977). The Grain of the Voice. In: Image, Music, Text. Essays selected and translated by Stephen Heath (pp. 179-189). London: Fontana Press.

Barthes, R. (2002). Le Grain de la voix. In: Marty, E. (Ed.), Roland Barthes, CEuvres complètes. IV. Livres, Textes, Entretiens, 1972-1976 (pp. 148-156). Paris: Seuil.

Blouin, M. J. (2011). A Western Wake: Difference and Doubt in Christopher Nolan's Inception. Extrapolation, 52(3), 318-337.

Brown, B. (2001). Thing Theory. Critical Inquiry, 28(1), 1-22.

Cavell, S. (2005). What Becomes of Things on Film? In Cavell, S. Cavell on Film, edited and with an introduction by William Rothman (pp. 1-10). Albany, NY: State University of New York Press.

Comolli, J.-L., \& Michelson, A. (1999). Documentary Journey to the Land of the Head Shrinkers. October, 90, 36-49.

Crain, C. (2010). Down The Rabbit Hole. The Paris Review. 21 July 2010. Accessed on 31 May 2013 on: http://www.theparisreview.org/blog/2010/07/21/down-the-rabbit-hole/

Enggelen, B. (2012). Why care whether the top keeps spinning? In Johnson, D. (Ed.) Inception and Philosophy: Because It's Never Just a Dream (pp. 108-122). The Blackwell philosophy and pop culture series. John Wiley \& Sons, Hoboken, NJ. 
Faraci, D. (2010). Never Wake Up: The Meaning and Secret of Inception. 19 July 2010. Accessed 31 May 2013 on: http://www.chud.com/24477/never-wake-up-the-meaning-and-secret-of-inception/

Fisher, M. (2011). The Lost Unconscious: Delusions and Dreams in Inception. Film Quarterly, 64(3), $37-45$.

Floury, N. (2011). Dreams, Mourning, and Desire. In Botz-Bornstein, Th. (Ed.) Inception and philosophy: ideas to die for (pp. 233-242). Chicago: Open Court.

Goldberg, M. (2010). Christopher Nolan (Somewhat) Explains Inception. November 24, 2010. Accessed 31 May 2013 on: http://collider.com/inception-christopher-nolan-explains/

Hadjioannou, M. (2012). From Light to Byte: Towards an Ethics of Digital Cinema. Durham, NC: Duke University Press.

Itzkoff, D. (2010). Hans Zimmer Extracts the Secrets of the 'inception' Score. ArtsBeat blog. The New York Times, July 28, 2010. Accessed 31 May 2013 on: http://artsbeat.blogs.nytimes. com/2010/07/28/hans-zimmer-extracts-the-secrets-of-the-inception-score/

Kerman, J. (1985). Musicology. London: Fontana.

Lerner, J. (2010). The Neuroscience of Inception. 26 July 2010. Accessed 31 May 2013 on: http://www. wired.com/wiredscience/2010/07/the-neuroscience-of-inception/

Mancini, V. (2010). FilmDrunk. 27 July 2010. Accessed 31 May 2013 on: http://filmdrunk.uproxx. $\mathrm{com} / 2010 / 07 /$ the-inception-music-is-really-just-other-music-slowed-down

Marks, L.U. (2000). The Skin of the Film. Intercultural Cinema, Embodiment, and the Senses. Durham, NC: Duke University Press.

Michaels, S. (2010). Inception soundtrack created entirely from Edith Piaf song. The Guardian. 29 July 2010. Accessed 31 May 2013 on: http://www.guardian.co.uk/music/2010/jul/29/inceptionsoundtrack-edith-piaf

Milner, M. (1999). L'anamorphose fantastique, ou la transfiguration de la vision par les instruments d'optique', Il paesaggio: Dalla percezione alla descrizione (pp. 45-56). Ed. Renzo Zorzi. Venice.

Neubauer, J. (2009). Organicism and Music Theory. In: Crispin, D., \& Snyers, K. (Eds.), New Paths: Aspects of Music Theory and Aesthetics in the Age of Romanticism (pp. 11-35). Collected Writings of the Orpheus Institute, 7. Leuven: Leuven University Press.

NPR blog. (2010). All Songs Considered. 2 August 2010. Accessed 31 May 2013 on: http://www.npr. org/blogs/allsongs/2010/08/02/128932586/the-music-of-inception-exposed

Ressner, J. (2012). The Traditionalist. Interview with Christopher Nolan. Accessed on 31 May 2013 on: http://www.dga.org/Craft/DGAQ/All-Articles/1202-Spring-2012/DGA-Interview-ChristopherNolan.aspx

Rodowick, D.N. (2007). The Virtual Life of Film. Cambridge, MA, London: Harvard University Press.

Rosar, W. (2009). Film Studies in Musicology: Disciplinarity vs. Interdisciplinarity. The Journal of Film Music, 2(2-4), 99-125.

Sobchack, V. (2006). Carnal Thoughts: Embodiment and Moving Image Culture. Berkeley: University of California Press.

Stern, L. (2004). Paths That Wind through the Thicket of Things. In: Brown, B. (Ed.), Things (pp. 393430). Chicago, London: The University of Chicago Press.

Taylor, H.M. The Junkies of Plato's Cave: inception, mindbending, and complex narration in the shadow of Philip K. Dick. Cineaction, 86, 4-13.

The Wall Street Journal (17 July 2010). Unsigned. Accessed 31 May 2013 on: http://blogs.wsj.com/ speakeasy/2010/07/17/whats-the-french-song-in-inception/ 


\section{Notes}

The author wishes to thank Rebecca Geoffroy-Schwinden, Guo-Juin Hong, Steen Kaargaard Nielsen and the two anonymous reviewers for their useful suggestions and remarks.

1 'I didn't intend to make a film about film-making, but I gravitated toward the creative process that I know' (Goldberg, 2010).

2 Also grounded on Faraci's reading, see Lerner, 2010.

3 Most of the special effects in Inception were realised without CGI by the special effects supervisor Chris Cobould (for which he won the Academy Award for Best Visual Effects and the BAFTA Award for Best Visual Effects). In his article, Mark Fisher writes, '[w] scious was, there CGI shall be' (2011, p. 40) echoing a largely held, ill-informed opinion that Inception relies on CGI techniques abundantly.

4 See also, Taylor, 2012; Crain, 2010.

5 See 'The Freight Train: Constructing the street-faring freight train', in the Special features of the DVD Warner Home Video, 2010.

6 'For the last 10 years, I've felt increasing pressure to stop shooting film and start shooting video, but I've never understood why' (Nolan: in Ressner, 2012).

7 For a most recent theoretical approach on the shift from celluloid film to digital media, see Hadjioannou, 2012, notably pp. 28-34.

8 Uploaded on 22 July 2010, by the user 'camian321'. Available: http://youtu.be/UVkQ0C4qDvM (accessed 31 May 2013).

9 This scansion reoccurs in other cues of the soundtrack, notably as a tenuous rhythmic pulse in the cue 'We built Our Own World'.

10 'The Inception music is really just other music slowed down' (Mancini, 2010). See also, Itzkoff, 2010; Michael, 2010; NPR blog, 2010.

11 Notably in 'Dream Is Collapsing,' 'Radical Notion', 'Waiting for the Train'.

12 'None of the arts has been affected more deeply than music by the ideology of organicism; its baleful influence is still very much with us' (Kerman, 1985, p. 65). Indeed as John Neubauer puts it, 'organicism is older than Romanticism and may outlive Postmodernism, for it is too multifarious to be condemned wholesale' (2009, p. 33).

13 Heard five times during the film.

14 There is a very abundant literature on this subject, to the point that one wonders if this has not become lately the main issue for justifying the existence of 'film music studies'. For an acute discussion of this, see Rosar, 2009.

15 See notably:

http://www.imdb.com/title/tt1375666/faq

http://movies.stackexchange.com/questions/1974/why-did-nolan-choose-non-je-neregrette-rien-as-a-kick-song-in-inception

http://www.inceptionending.com/theory/10-things-you-probably-didnt-know-about-inception/

http://www.nolanfans.com/forums/viewtopic.php?f=34\&p=52394

(All accessed 31 May 2013).

The hermeneutic approach associating the lyrics with Cobb's struggle with his remorse is favoured in two recent publications: see Enggelen, 2012, p. 119, and Floury, 2011, pp. 238-239.

16 A survey I made between the months of August and December 2010 on a poll of 68 persons, mostly undergraduate students and faculty at Duke University (thus avoiding possibly any Francophone participants, since in French-speaking countries Piaf and her songs are extremely well-known), shows that 23 viewers did not notice that there was a song. As for the 45 viewers who were aware of the song (that is to say, who either recognised the song or had 
'a vague idea' of the song and or its singer), 31 thought that the song had been chosen because of its meaning. See the results of the poll in the annex 1. That being said, no major conclusion should be drawn from this poll, considering the small pool of participants (68) and the inevitable bias provided by the multiple-choice answers to the questions.

17 The 'Play it once, Sam, for old times' sake', said by Ilsa Lund (Ingrid Bergman) to the pianist, has become widely known, and misquoted, in popular culture, as 'Play it again, Sam'.

18 See, for instance, Blouin, 2011, pp. 329-330.

19 The phéno-song is 'in short, everything in the performance which is in the service of communication, representation, expression, everything which it is customary to talk about, which forms the tissue of cultural values (the matter of acknowledged tastes, of fashions, of critical commentaries), which takes its bearing directly on the ideological alibis of a period ("subjectivity", "expressivity”, “dramaticism”, "personality” of the artist)' (Barthes, 1977, p. 182; Barthes, 2002, p. 150 for the original quotation).

20 Embedded in Zimmer's score, the song starts with the full introduction but then moves directly to the $4^{\text {th }}$ and $5^{\text {th }}$ couplets, the latter remaining incomplete as the final verse is not heard; after the verse 'Car ma vie, car mes joies' the song fragment reoccurs in a slowed down speed.

21 Artur: 'We could use a musical countdown to synchronize the different kicks'; Ariadne: 'OK, as soon as Artur's music kicks in, just use the defibrillator to revive him. [...] As soon as the music ends, you blow up the hospital and we all ride the kick back up the layers'.

22 '[L]a zone périphérique est constituée par ce que l'on pourrait appeler des signes décrochés, où l'analogie entre le signifiant et le signifié est en quelque sorte disjointe, inattendue' .

23 Anamorphosis is usually understood as a deformation of the visual perception. The point of view is being refocused not on the foreground of an image, but on a background detail, itself being in turn submitted to endless multiplications. As in a kaleidoscope, the detail totally invades the image, rendering it unrecognisable. See Milner, 1999.

24 One can easily grasp the psychoanalytic metaphors on offer here, with the quasi-organic quality of the cord as umbilical device and the silicone button looking like a breathing membrane or a matricial vital pump.

25 In his unpublished paper 'Film songs and things' delivered at the 2010 AMS/SMT meeting (Indianapolis), Berthold Hoeckner also relies on Brown's thing theory to invoke the thingness of songs, yet in a different context, as he views these as 'memory objects'.

26 Let us mention, for instance, the recent vogue for photographic applications, such as Instagram or Hipstamatic, that recreate, at the visual level, a similar 'vintage effect'. 